\title{
New records of red brocket deer (Mazama temama) in cloud forests in northeastern Hidalgo, México
}

\section{Nuevos registros del venado temazate (Mazama temama) en bosques mesófilos del noreste de Hidalgo, México}

\author{
Germán Manzanero-Barrera ${ }^{1}$, Izchel Gabriela Vargas-Jiménez², and Alejandro Flores-Manzanero 3 , 4* \\ ${ }^{1}$ Servicios Forestales de Hidalgo, SERFORH S.C. Ciruelos 135, Col. Fraccionamiento Las Peras, CP. 42184, Mineral de la Reforma, \\ Hidalgo, México. Email: manzanero.barrera@gmail.com (GM-B). \\ ${ }^{2}$ Laboratorio de Vertebrados Terrestres (Mastozoología), Centro Interdisciplinario de Investigación para el Desarrollo Integral \\ Regional, Unidad Oaxaca, Instituto Politécnico Nacional. Hornos 1003, Col. Noche Buena, Santa Cruz Xoxocotlán, CP. 71230, \\ Oaxaca, México. Email: izchelvargasjimenez@gmail.com (IGV-J). \\ ${ }^{3}$ Departamento de Ecología de la Biodiversidad, Instituto de Ecología, Universidad Nacional Autónoma de México. 3er Circuito \\ Exterior, Anexo Jardín Botánico, Ciudad Universitaria, CP. 04510, Ciudad de México, México. Email: floresmanzanero10@ \\ gmail.com (AF-M). \\ ${ }^{4}$ Posgrado en Ciencias Biológicas, Universidad Nacional Autónoma de México, Coyoacán, CP. 04510, Ciudad de México, México. \\ *Corresponding author
}

The red brocket deer (Mazama temama) is one of the least studied species of deer in Latin America. In México, little information is available on this species in mountainous regions, particularly in mountain cloud forests (MCF) in the state of Hidalgo. Since red brocket deer and MCF are threatened, mainly by anthropogenic activities, it is essential to carry out monitoring to corroborate the presence of this species in the MCF of Hidalgo. Here we report new records of this species in MCF of northeastern Hidalgo, in a forest management unit. The study was carried out in the 1302 Zacualtipán-Molango Forest Management Unit (UMAFOR) as part of the Strengthening of Social Organizations in the Forestry Sector project of the 2016 National Forestry Program. Monthly walks were carried out in different locations (sites) within the area between January 2016 and February 2019. The presence of red brocket deer was inferred from evidence of scats, tracks, direct sightings, and photographic records. For the latter, trap cameras were placed at sites identified as likely wildlife passes. We obtained 20 records ( 1 track, 2 scats, 1 sighting, 16 photographs) of red brocket deer. The sighting consisted of an adult individual being chased by seemingly feral dogs. These records provide up-to-date information on the distribution of red brocket deer in MCF in northeastern Hidalgo. To note, records were obtained in an area subjected to forest use under sustained anthropogenic impact. However, owners dedicate their premises to conservation, specifically those including MCF. Since red brocket deer thrives in conserved forests, the records reported here suggest positive effects of forest management on this UMAFOR. Biological monitoring in the area should be continued and extended, also covering areas subject to forest exploitation, as feral dogs may undermine red brocket deer populations. Finally, we recommend the development of research projects in the area, to contribute to management plans aiming to preserve red brocket deer populations.

Key words: Anthropogenic impact; cervid species; feral dogs; forest management.

El venado temazate (Mazama temama) es una de las especies de cérvidos menos estudiados en América Latina. En México, se tiene poca información de esta especie en regiones montañosas, particularmente en bosques mesófilos de montaña (BMM) del estado de Hidalgo. Dado que el venado temazate y los BMM se encuentran amenazados, principalmente por las actividades antropogénicas, es importante realizar monitoreos para corroborar la presencia de esta especie en los BMM de la entidad. Presentamos nuevos registros de esta especie en bosques mesófilos del noreste de Hidalgo, en una unidad de manejo forestal. El estudio se realizó en la Unidad de Manejo Forestal (UMAFOR) 1302 Zacualtipán-Molango, como parte del proyecto Fortalecimiento de las Organizaciones Sociales del Sector Forestal, del Programa Nacional Forestal 2016. Se llevaron a cabo recorridos mensuales en diferentes localidades (predios) de la zona, entre enero de 2016 a febrero de 2019. La presencia de venado temazate se verificó mediante el hallazgo de excretas, huellas, avistamientos directos y registros fotográficos. Para esto último, se colocaron cámaras trampa en sitios identificados como posibles pasos de fauna. Obtuvimos 20 registros (1 huella, 2 excretas, 1 avistamiento, 16 fotografías) de venado temazate. El avistamiento consistió en un individuo adulto que era perseguido por perros, aparentemente ferales. Estos registros aportan información actualizada acerca de la distribución del venado temazate en BMM del noreste de Hidalgo. Destacamos que los registros se obtuvieron en una zona de aprovechamiento forestal donde existe impacto antropogénico constante. Sin embargo, las personas destinan en sus predios áreas para conservación, específicamente los BMM. Dado que esta especie es considerada especialista de bosque conservado, los registros podrían indicar impactos positivos del manejo forestal en esta UMAFOR. Se deben continuar y extender los monitoreos biológicos en el área, abarcando también las zonas sujetas a aprovechamiento forestal ya que se observaron perros ferales que pueden vulnerar las poblaciones de venado temazate. Finalmente, exhortamos el desarrollo de proyectos de investigación en el área, para contribuir a los planes de manejo con el objetivo de la persistencia de las poblaciones de venado temazate.

Palabras clave: Especies de cérvidos; impacto antropogénico; manejo forestal; perros ferales. 
The red brocket deer, Mazama temama (Kerr 1792), is one of the least studied species of deer in Latin America in terms of biology, ecology, distribution, and other aspects (Weber and González 2003; Mandujano 2004; Gallina 2005; Gallina and Mandujano 2009; Mandujano 2011). As a result, the International Union for the Conservation of Nature (IUCN) lists this species as Data Deficient, indicating that it cannot be included in the red list of threatened species until its distribution range and other ecological aspects are better defined (Bello et al. 2016). Similarly, the limited information available for the species in México, particularly about its distribution, explains why it is currently not listed in any risk category (SEMARNAT 2010) despite being considered a conservation priority (SEMARNAT 2014). Its historical distribution includes southern México, Belize, Guatemala, El Salvador, Costa Rica, Nicaragua, Honduras, Panama, and western Colombia (Bello et al. 2010, 2016); in México, it is reported in the states of Tamaulipas, San Luis Potosi, Veracruz, Hidalgo, Oaxaca, Chiapas, Tabasco, Campeche, and Quintana Roo (Jones et al. 1983; Gallina 2005; Bello et al. 2016).

The red brocket deer inhabits mainly high evergreen and medium subdeciduous tropical forests, and mountain cloud forests (MCF); it has also been reported in temperate pine-oak forests (Bello et al. 2010). It commonly thrives in areas with dense vegetation coverage, high water availability, and low anthropogenic pressure (Weber 2008). Its presence has also been reported in patches of secondary vegetation near to more conserved MCF fragments (Lira-Torres and Naranjo 2003; Pérez-Solano et al. 2012, 2016).

MCF are recognized worldwide for their high biodiversity levels and the hydrological services provided. In México, these forests are considered one of the most threatened terrestrial ecosystems due to the small area covered (less than 1 $\%)$, and the constant anthropogenic impact associated with changes in land use (Challenger and Soberón 2008; CONABIO 2010; Ponce-Reyes et al. 2012; López-Arce et al. 2019).

Particularly, mountain cloud forests located in the state of Hidalgo are considered to be of high priority for conservation due to pressures related to extensive livestock, agriculture, and selective logging (CONABIO 2010). Of the two MCF subregions in the entity (CONABIO 2010), research work on red brocket deer has been carried out and published for the San Bartolo Tutotepec-Cuetzalan Cloud Forest subregion (Muñoz and Gallina 2014; Muñoz-Vazquez and Gallina-Tessaro 2016). In contrast, there are scarce research projects and little knowledge about biodiversity for MCFs in the other subregion, named Northeastern Hidalgo-Huayacocotla Cloud Forests (SERFORH 2017).

Since little is known about the current distribution of red brocket deer in mountainous regions of México (OrtízGarcia et al. 2012; Pérez-Solano et al. 2012; Ramírez-Bravo and Hernández-Santín 2012; Pérez-Solano and Mandujano 2013; Pérez-Solano et al. 2016), particularly in the state of Hidalgo (Muñoz and Gallina 2014; Muñoz-Vazquez and Gallina-Tessaro 2016), medium - and long - term monitoring in MCF of this state is deemed essential. In this note, we report new records of red brocket deer in Northeastern Hidalgo-Huayacocotla Cloud Forests, which supplement records reported for the San Bartolo Tutotepec MCF (Muñoz and Gallina 2014; Muñoz-Vazquez and Gallina-Tessaro 2016) and contribute with additional information on the current distribution of this species. Particularly relevant are the photographic records obtained in an area subjected to forest exploitation, which is poorly researched despite it represents an important site for biodiversity conservation.

The study was carried out in the 1302 Zacualtipán-Molango Forest Management Unit (UMAFOR), an area comprising 228,341.94 ha (SERFORH 2011; Figure 1). It is located to the northeast of the state of Hidalgo (20 $58^{\prime} 34^{\prime \prime}-20^{\circ} 23^{\prime} 15^{\prime \prime}$ $\mathrm{N}, 9^{\circ} 57^{\prime} 56^{\prime \prime}-98^{\circ} 25^{\prime} 12^{\prime \prime} \mathrm{W}$ ) and encompasses 8 municipalities: Calnali, Juárez Hidalgo, Metztitlán, Molango de Escamilla, San Agustín Metzquititlán, Tianguistengo, Xochicoatlán, and Zacualtipán de Ángeles.

MCF is the most widely distributed vegetation type in this UMAFOR, stretching across an area of 62,177.51 ha (SERFORH 2011; Figure 1). On the other hand, the dominant vegetation types in the localities studied within the UMAFOR (sites) are pine-oak and oak-pine forests subjected to forestry management (SERFORH 2011). It is worth mentioning that the sites studied have been under this forest management scheme since the 1980s, and their forest zoning programs consider MCFs as conservation and non-use zones (SERFORH 2011). The mammal species recorded in MCFs include lion mountain (Puma concolor), margay (Leopardus wiedii), tayra (Eira barbara), white-tailed deer (Odocoileus virginianus), and collared peccary (Pecari tajacu; SERFORH 2017). Some sites are currently managed under the pay-forenvironmental-services scheme, involving monitoring brigades to prevent poaching; however, subsistence hunting is practiced in forestry areas (SERFORH 2011, 2017).

As part of the field work of the Strengthening of Social Organizations in the Forestry Sector project, 2016 National

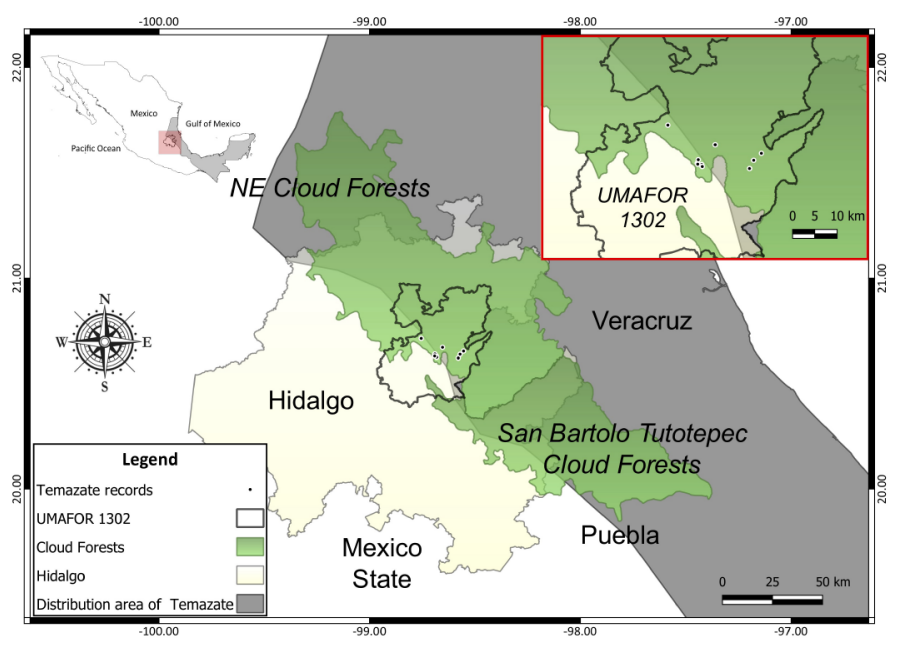

Figure 1. Study area and location of records of red brocket deer (Mazama temama) in mountain cloud forests in northeastern Hidalgo, México. Known distribution of Mazama temama (IUCN 2016), the two mountain cloud forest regions of Hidalgo: Northeastern (NE)-Huayacocotla Cloud Forest and San Bartolo Tutotepec-Cuetzalan Cloud Forest (CONABIO 2010), as well as the 1302 Zacualtipán-Molango Forest Management Unit (UMAFOR) polygon are shown. 
Forestry Program, monthly walks across different sites were conducted for 3 years (January 2016 to February 2019). The distance covered in each walk was $1 \mathrm{~km}$ minimum, depending on the orography of the site studied, with 2 walks per month. Walks were carried out in the morning ( 8 am to 3 $\mathrm{pm})$; the presence of red brocket deer was inferred from indirect evidence, mainly scats and tracks, using illustrated field guides to support each determination (Aranda-Sánchez 2012). The accuracy of records was further confirmed by placing 7 camera traps model Bushnell ${ }^{\circ}$ Trophy ${ }^{\circ}$ Cam HD (Bushnell ${ }^{\circ}$ ) at sites previously identified as wildlife passes. Camera traps were spaced about $500 \mathrm{~m}$ to $1 \mathrm{~km}$ apart, and were set to capture 3 images per detection event; traps operated 24 hours a day for 30 days in each location. The camera-trap sampling period covered the dry and rainy seasons of the year, with a total of 90 days trap per year. Finally, the sampling effort was calculated by multiplying the total number of camera traps by the total number of sampling days (trap nights), as reported for medium- and large - sized mammals (Hernández-Pérez et al. 2015).
Camera traps were placed in forest trails, firewall gaps, adjacent to streams, forestry areas, and conservation areas (Table 1). From the photographic records obtained, red brocket deers were identified based on the physical characters described for the species and applying quality filters to photographs (Reid 1997; Gallina 2005; Lara-Díaz et al. 2011; Aranda-Sánchez 2012).

We obtained 20 records of red brocket deer over the 3 years of sampling (2016: $n=5,2017: n=3,2018: n=7,2019$ : $n=5)$, which correspond to scats $(n=2)$, tracks $(n=1)$, sightings $(n=1)$, and photographic records ( $n=16$; Table 1$)$. The total sampling effort over the 3 years was at least 48 linear kilometers (walks) and 1,890 trap-nights (camera traps).

One of the scats records was found in a trail within the area dedicated to conservation in Ejido Olotla, municipality of Metztitlán. The second scat was found in a forest trail along the protection strip within the Apaxtitla site, which is under forest management. The record corresponding to the track was found in a trail within the Tetenatipa site, which is under forest management, located $2 \mathrm{~km}$ from the

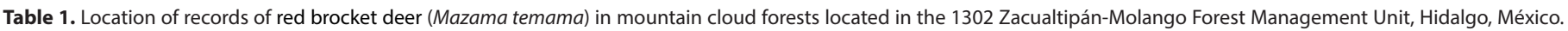
$n$ : number of records.

\begin{tabular}{|c|c|c|c|c|c|c|c|c|}
\hline Record & Location & Municipality & Latitude & Longitude & $\mathbf{n}$ & Age & Observations & Month, year \\
\hline Scat & Predio Apaxtitla & $\begin{array}{l}\text { Zacualtipán de } \\
\text { Ángeles }\end{array}$ & $\begin{array}{l}20^{\circ} 38^{\prime} \\
21.52^{\prime \prime}\end{array}$ & $\begin{array}{l}98^{\circ} 34^{\prime} \\
17.57^{\prime \prime}\end{array}$ & 1 & Undefined & $\begin{array}{l}\text { In a forest trail within a conser- } \\
\text { vation area, Apaxtitla private } \\
\text { premises. }\end{array}$ & February, 2016 \\
\hline Scat & Ejido Olotla & Metztitlán & $\begin{array}{l}20^{\circ} 37^{\prime} \\
48.40^{\prime \prime}\end{array}$ & $\begin{array}{l}98^{\circ} 40^{\prime} \\
59.04^{\prime \prime}\end{array}$ & 1 & Undefined & $\begin{array}{l}\text { In a trail by a stream, within the } \\
\text { conservation area } 5 \mathrm{~km} \text { from } \\
\text { Olotla. }\end{array}$ & March, 2016 \\
\hline Sighting & Predio Cruxtitla & $\begin{array}{l}\text { Zacualtipán de } \\
\text { Ángeles }\end{array}$ & $\begin{array}{l}20^{\circ} 39^{\prime} \\
15.87^{\prime \prime}\end{array}$ & $\begin{array}{l}98^{\circ} 33^{\prime} \\
17.45^{\prime \prime}\end{array}$ & 1 & Adult & $\begin{array}{l}\text { Cruxtitla, land under forest use. } \\
\text { Specimen chased by feral dogs } \\
\text { observed during a transect review. }\end{array}$ & August, 2016 \\
\hline Photo-record-4 & Ejido Olotla & Metztitlán & $\begin{array}{l}20^{\circ} 37^{\prime} \\
32.8^{\prime \prime}\end{array}$ & $\begin{array}{l}98^{\circ} 40^{\prime} \\
54.5^{\prime \prime}\end{array}$ & 2 & $\begin{array}{l}\text { Adults (female } \\
\text { and male) }\end{array}$ & $\begin{array}{l}10 \mathrm{~m} \text { from a stream, within the } \\
\text { conservation area. }\end{array}$ & August, 2016 \\
\hline Photo-record-3 & Ejido Olotla & Metztitlán & $\begin{array}{l}20^{\circ} 38^{\prime} \\
25.88^{\prime \prime}\end{array}$ & $\begin{array}{l}98^{\circ} 41^{\prime} \\
25.95^{\prime \prime}\end{array}$ & 2 & $\begin{array}{l}\text { Fawn and } \\
\text { yearling }\end{array}$ & $\begin{array}{l}\text { On a firewall gap, within the areas } \\
\text { under forest management, delim- } \\
\text { iting the area under recovery. }\end{array}$ & $\begin{array}{l}\text { January and } \\
\text { February, } 2017\end{array}$ \\
\hline Photo-record-6 & $\begin{array}{l}\text { Ejido Santo } \\
\text { Domingo }\end{array}$ & $\begin{array}{l}\text { Zacualtipán de } \\
\text { Ángeles }\end{array}$ & $\begin{array}{l}20^{\circ} 37^{\prime} \\
17.03^{\prime \prime}\end{array}$ & $\begin{array}{l}98^{\circ} 34^{\prime} \\
48.36^{\prime \prime}\end{array}$ & 1 & Adult (male) & $\begin{array}{l}\text { On a forest gap, within the areas } \\
\text { under forest management. }\end{array}$ & August, 2017 \\
\hline Photo-record-5 & Ejido Olotla & Metztitlán & $\begin{array}{l}20^{\circ} 37^{\prime} \\
34.5^{\prime \prime}\end{array}$ & $\begin{array}{l}98^{\circ} 40^{\prime} \\
57.5^{\prime \prime}\end{array}$ & 3 & Adult (females) & $\begin{array}{l}10 \mathrm{~m} \text { from a stream running across } \\
\text { the conservation area. }\end{array}$ & March, 2018 \\
\hline Photo-record-7 & $\begin{array}{l}\text { Ejido San } \\
\text { Agustín }\end{array}$ & Eloxochitlán & $\begin{array}{l}20^{\circ} 42^{\prime} \\
53.46^{\prime \prime}\end{array}$ & $\begin{array}{l}98^{\circ} 45^{\prime} \\
20.96^{\prime \prime}\end{array}$ & 1 & Adult (male) & $\begin{array}{l}\text { In a gap adjacent to the stream in } \\
\text { San Agustín Eloxochitlán, within } \\
\text { the conservation area. }\end{array}$ & August, 2018 \\
\hline Photo-record-1 & $\begin{array}{l}\text { Bienes Comu- } \\
\text { nales Olotla }\end{array}$ & Metztitlán & $\begin{array}{l}20^{\circ} 37^{\prime} \\
58.83^{\prime \prime}\end{array}$ & $\begin{array}{l}98^{\circ} 41^{\prime} \\
34.11^{\prime \prime}\end{array}$ & 3 & $\begin{array}{l}\text { Adults ( } 1 \\
\text { female and } 2 \\
\text { males) }\end{array}$ & $\begin{array}{l}\text { On a firewall gap delimiting Olotla } \\
\text { and Bienes Comunales Olotla. }\end{array}$ & November, 2018 \\
\hline Photo-record-2 & $\begin{array}{l}\text { Bienes Comu- } \\
\text { nales Olotla }\end{array}$ & Metztitlán & $\begin{array}{c}20^{\circ} 37^{\prime} \\
51.0^{\prime \prime}\end{array}$ & $\begin{array}{c}98^{\circ} 41.3^{\prime} \\
30.0^{\prime \prime}\end{array}$ & 4 & $\begin{array}{l}\text { Adults ( } 3 \\
\text { females and } 1 \\
\text { male) }\end{array}$ & $\begin{array}{l}\text { On a firewall gap, within the areas } \\
\text { under forest management. }\end{array}$ & February, 2019 \\
\hline Track & $\begin{array}{l}\text { Predio Tete- } \\
\text { natipa }\end{array}$ & $\begin{array}{l}\text { Zacualtipán de } \\
\text { Ángeles }\end{array}$ & $\begin{array}{l}20^{\circ} 40^{\prime} \\
20.37^{\prime \prime}\end{array}$ & $\begin{array}{l}98^{\circ} 39^{\prime} \\
14.80^{\prime \prime}\end{array}$ & 1 & Undefined & $\begin{array}{l}\text { On a gap, in the Tetenatipa private } \\
\text { premises subjected to forest man- } \\
\text { agement, } 2 \text { km from Zacualtipán } \\
\text { de Ángeles. }\end{array}$ & July, 2019 \\
\hline
\end{tabular}


urban area in the municipality of Zacualtipán de Angeles. The sighting occurred within the Cruxtitla site, also under forest management. During a survey walk of transects across this site, an adult red brocket deer was observed being chased by a pack of dogs (apparently unguarded by people), which were after it until leaving the area.

The rest of records were photographic evidence. Two adult individuals were recorded in August 2016, 1 female and 1 male. In 2017, 3 specimens were recorded, corresponding to one fawn, one yearling, and one adult, in January, February and August, respectively (Figure 2). In 2018, 7 records were obtained: 3 adult females in March, one adult male in August, and 2 adult males plus one adult female in November. Finally, 4 records were obtained in February 2019, corresponding to 3 adult females and 1 adult male. Of the photographic records, 11 were captured during the night (between 6:45 pm and $1 \mathrm{am}$ ) and 5 during the day (between 8 am and 3 pm).

The records of red brocket deer reported in this note provide relevant information about its current distribution in the state of Hidalgo, México, and contribute to the information available on the conservation status of this cervid species (SEMARNAT 2010; Bello et al. 2016). Our work is a contribu-
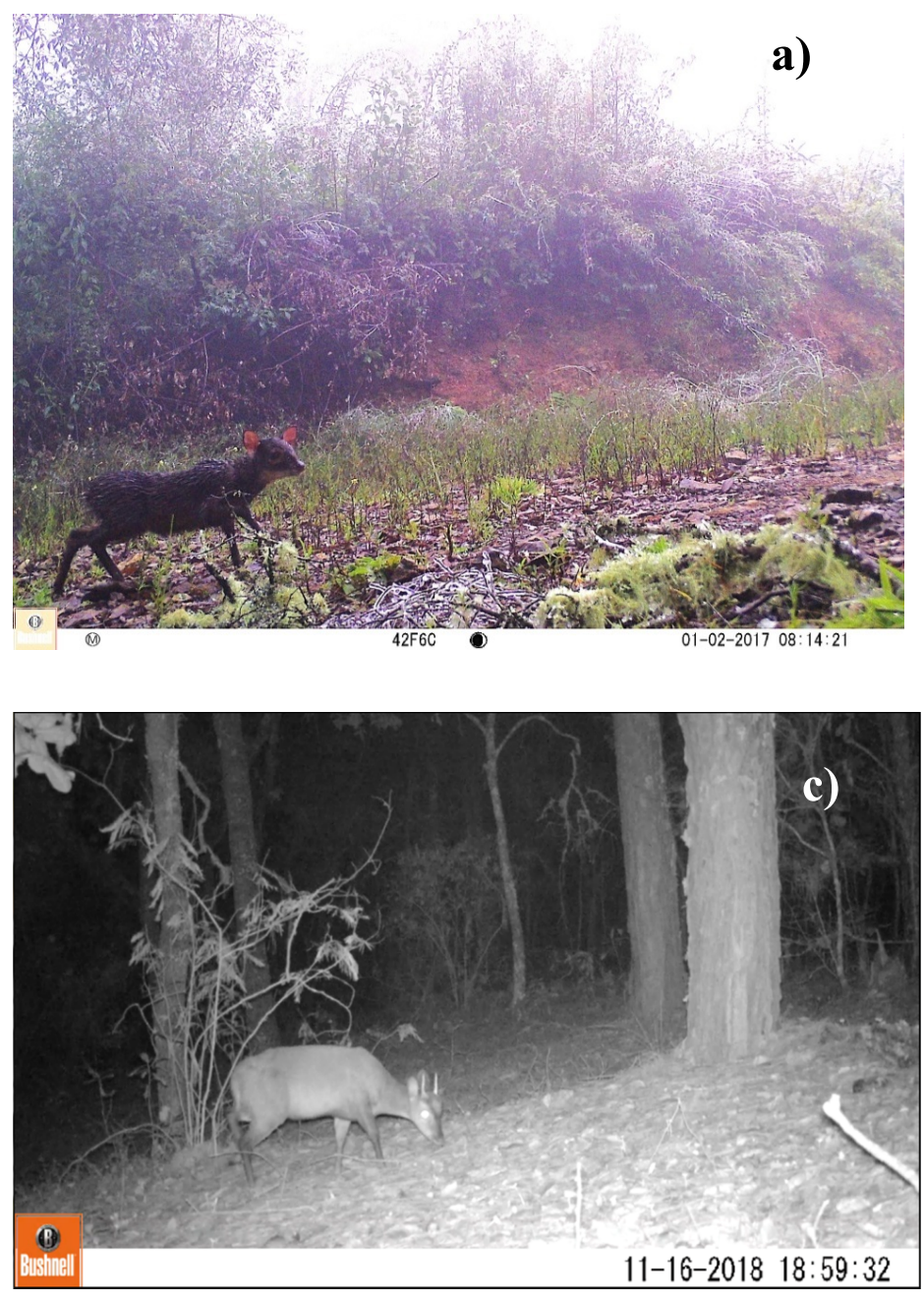

tion to the few studies carried out on this species in the MCF of Hidalgo (Muñoz and Gallina 2014; Muñoz-Vazquez and Gallina-Tessaro 2016), being among the early works covering Northeastern Hidalgo-Huayacocotla Cloud Forest subregion.

The records were obtained in the UMAFOR's MCF, a managed forest where the main anthropogenic impact is the land use change for forest activities, including selective logging (CONABIO 2010; SERFORH 2011). Regarding this, habitat fragmentation and human presence have been reported to adversely impact red brocket deer populations; hence, this species is considered to be an inner-forest specialist in different regions of México (Reyna-Hurtado and Tanner 2005; Ortiz-Garcia et al. 2012; Ramírez-Bravo and Hernández-Santín 2012; García-Marmolejo et al. 2015; Contreras-Moreno et al. 2016; Pérez-Irineo and Santos-Moreno 2016), particularly in San Bartolo Tutotepec Mountain Cloud Forest, Hidalgo (Muñoz and Gallina 2014; MuñozVazquez and Gallina-Tessaro 2016). In our study, carried out on some MCF sites in the Northeastern Hidalgo-Huayacocotla subregion, community companies classify these forests as conservation areas exempted from any sort of forest use (SERFORH 2011), resulting in areas of dense vegetation cover surrounding disturbed sites. Thus, the presence of
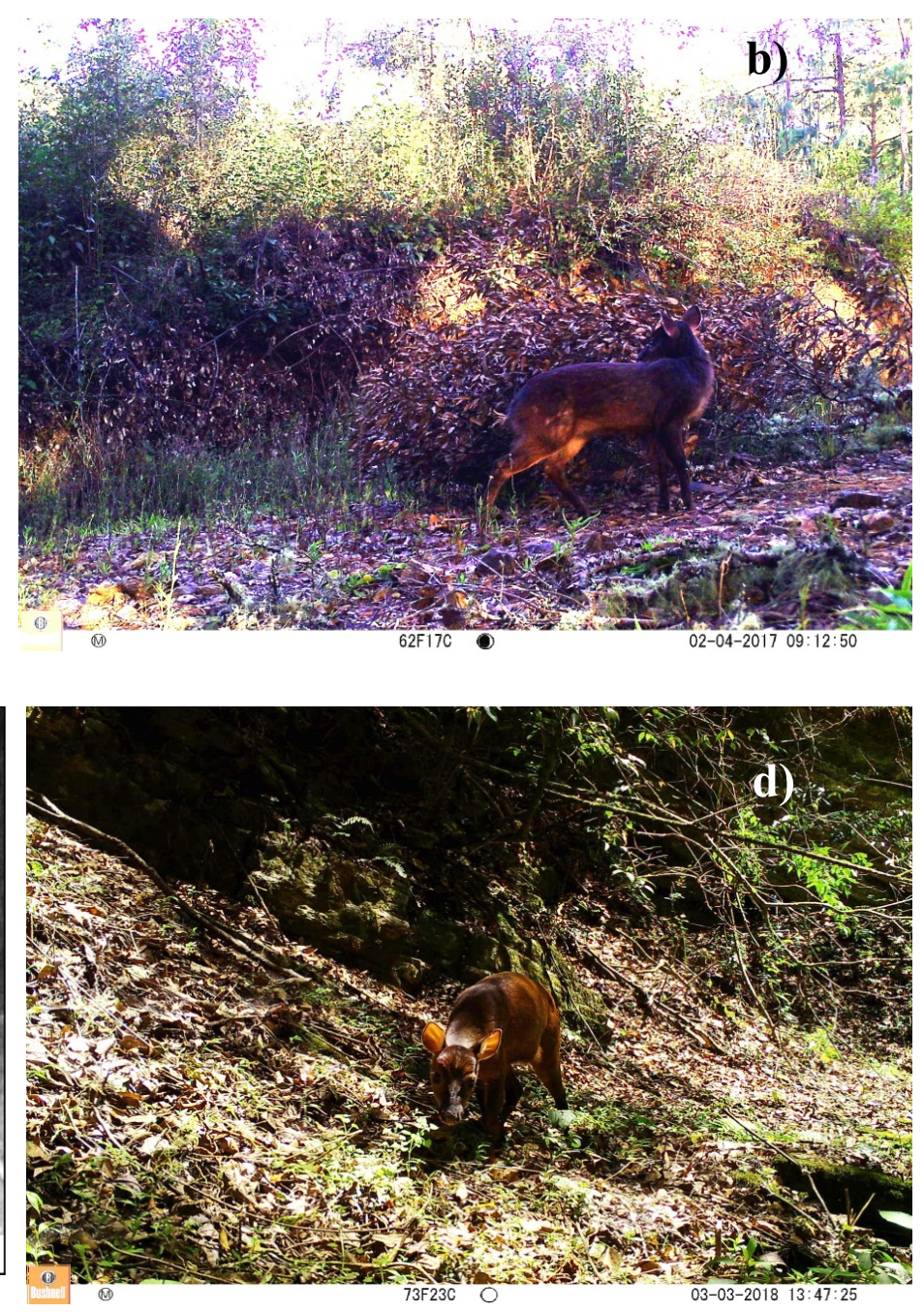

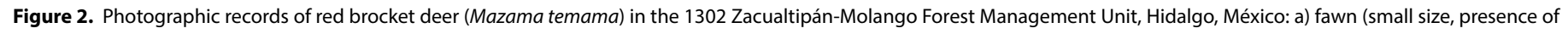
white spots along the back), b) yearling or adult female, c) male (small, unbranched antlers), d) yearling or adult female. 
red brocket deer in this UMAFOR could be associated with the existence of MCF, as reported elsewhere (Lira-Torres and Naranjo 2003; Reyna-Hurtado and Tanner 2007). Given the above, MCFs in northeastern Hidalgo may represent the northernmost shelters for red brocket deer populations, which could be connected with San Bartolo Tutotepec MCFs (Muñoz-Vazquez and Gallina-Tessaro 2016).

In this regard, community forests in México have been documented as high species richness sites because owners set limits on deforestation and degradation of the forest cover, hence promoting biodiversity conservation (Bray et al. 2007; CONAFOR 2016). Similarly, the adoption of a socioecological approach where the use of natural resources considers the interactions between the social and natural environments, has been proposed as a successful management approach for the conservation of wildlife species in fragmented environments, particularly the red brocket deer (García-Marmolejo et al. 2015). Therefore, our results suggest positive impacts of forest management on this UMAFOR. This finding may be further confirmed through additional monitoring in areas under forest exploitation, using specific methods to estimate population abundance and density (see Lara-Díaz et al. 2011), coupled with more accurate assessments of the impact of forest management on red brocket deer populations (Muñoz-Vazquez and Gallina-Tessaro 2016). It is worth stressing that this forest management scheme has contributed to reducing the negative impacts on mammalian diversity (Hernández-Rodríguez et al. 2019); therefore, this UMAFOR may be considered a management scheme that is compatible with the conservation of priority species.

On the other hand, the presence of seemingly feral dogs in the study area demonstrates the importance of continuing the monitoring efforts in this and other management units, since red brocket deer are preyed upon by them (Weber and González 2003; Mandujano 2011). UMAFOR units are areas with little published information about the species they harbor, especially mammals (SERFORH 2017). Additionally, our photographic records suggest that red brocket deer is particularly active at night in the MCF located at this UMAFOR, which could be interpreted as a strategy to evade humans and its activities, including poaching (Reyna-Hurtado and Tanner 2005).

Our results suggest that UMAFORs may supplement the protection provided by natural areas of high conservation priority, including MCFs (Challenger and Soberón 2008; CONABIO 2010), which harbor priority species such as red brocket deer (SEMARNAT 2014). Finally, we encourage the development of research projects at this UMAFOR specifically addressing the red brocket deer. These will contribute to a better understanding on its ecology, ethnoecology, ethology, and genetics (Weber and González 2003; Mandujano 2004; Reyna-Hurtado and Tanner 2005; Gallina and Mandujano 2009; Escobedo-Morales et al. 2016), and will set the groundwork for the development of management and conservation plans for this species populations.

\section{Acknowledgements}

To the Association of Forest Managers of the ZacualtipánMolango Region, who kindly granted permission to carry out monitoring within areas under forest management, and for their constant company during field trips. To F. Martínez-Pérez and H. A. González-Moreno for the assistance and financial support provided during the monitoring. To our coworkers, J. C. Badillo-Rojas and D. Lucio-Bautista. M. E. Sánchez-Salazar translated the manuscript into English.

\section{Literature cited}

Aranda-Sánchez, J. M. 2012. Manual para el rastreo de mamíferos silvestres de México. CONABIO. México City, México.

Bello, J., R. Reyna-Hurtado, and J. Wilham. 2010. Central American Red Brocket Deer Mazama temama Kerr 1792. Pp. 166-171 in Neotropical cervidology: biology and medicine of Latin American deer (Duarte, J. M. B, and S. González, eds.). IUCN/FUNEP. Gland, Switzerland.

Bello, J., R. Reyna., And J. Schipper. 2016. Mazama temama. In: IUCN 2016. The IUCN Red List of Threatened Species. Ver. 2016-2. https://www.iucnredlist.org. Downloaded on 2 September 2019.

Bray, D. B., E. Durán-Medina, L. Merino-Pérez, J. M. TorresRojo, and A. Velázquez-Montes. 2007. Nueva evidencia: Los bosques comunitarios de México protegen el ambiente, disminuyen la pobreza y promueven la paz social. Agrupación Sierra S.C. y Consejo Civil Mexicano para la Silvicultura Sostenible A. C., México City, México.

Challenger, A., and J. Soberón. 2008. Los ecosistemas terrestres. Pp. 87-108 in Capital natural de México, Vol. 1: Conocimiento actual de la biodiversidad (Soberón, J., G. Halffter, y J. Llorente-Bousquets, comps.). CONABIO. México City, México.

Comisión Nacional para el Conocimiento y Uso de la BiodiversIDAD (CONABIO). 2010. El Bosque Mesófilo de Montaña en México: Amenazas y Oportunidades para su Conservación y Manejo Sostenible. CONABIO. México City, México.

Comisión Nacional Forestal (CONAFOR). 2016. Manual de mejores prácticas de manejo forestal para la conservación de la biodiversidad en ecosistemas tropicales de la región sureste de México. CONABIO, PNUD, GEF. México City, México.

Contreras-Moreno, F. M., K. De la Cruz-Félix, J. Bello-Gutiérrez, and M. G. Hidalgo-Minart. 2016. Variables del paisaje que determinan la presencia de los venados temazates (Mazama sp.) en el oeste del estado de Campeche, México. Therya 7:3-19.

Escobedo-Morales, L. A., S. Mandujano, L. E. Eguiarte, M. A. Rodríguez-Rodríguez, ANd J. E. Maldonado. 2016. First phylogenetic analysis of Mesoamerican brocket deer Mazama pandora and Mazama temama (Cetartiodactyla: Cervidae) based on mitochondrial sequences: Implications for Neotropical deer evolution. Mammalian Biology 81:303-313.

Galuina, S. 2005. Temazate (Mazama americana). Pp. 512-513 in Los mamíferos silvestres de México (Ceballos, G., y G. Oliva, coords.). CONABIO, Fondo de Cultura Económica. México City, México.

Gallina, S., and S. Mandujano. 2009. Research on ecology, conservation and management of wild ungulates in Mexico. Tropical Conservation Science 2:116-127. 
García-Marmolejo, G., L. Chapa-Vargas, M. Weber, and E. HuberSANNWALD. 2015. Landscape composition influences abundance patterns and habitat use of three ungulate species in fragmented secondary deciduous tropical forests, Mexico. Global Ecology and Conservation 3:744-755.

Hernández-Pérez, E., R. Reyna-Hurtado, G. Castillo Vela, M. SanVICENTE-López, AND J. F. Moreira-Ramírez. 2015. Fototrampeo de mamíferos terrestres de talla mediana y grande asociados a petenes del noroeste de la península de Yucatán, México. Therya 6:559-574.

Hernández-Rodríguez, E., L. Escalera-Vázquez, J. M. Calderón-Patrón, and E. Mendoza. 2019. Mamíferos medianos y grandes en sitios de tala de impacto reducido y de conservación en la sierra Juárez, Oaxaca. Revista Mexicana de Biodiversidad 90:e902776.

Jones, J. K., D. C. Carter, And W. D. Webster. 1983. Records of Mammals from Hidalgo, Mexico. The Southwestern Naturalist 283:378-380.

Lara-Díaz, N. E., H. Coronel-Arellano, A. González-Bernal, C. Gutiérrez-GonzÁlez, AND C. A. López-GonzÁlez. 2011. Abundancia y densidad de venado cola blanca (Odocoileus virginianus couesi) en Sierra de San Luis, Sonora, México. Therya 2:125-137.

Lira-Torres, I., AND E. Naranjo. 2003. Abundancia, preferencias de hábitat e impacto del ecoturismo sobre el puma y dos de sus presas en la reserva de la biósfera El Triunfo, Chiapas, México. Revista Mexicana de Mastozoología 7:20-39.

López-Arce, L., C. UReta, D. Granados-Sánchez, L. Rodríguez-EsPARZA, AND A. Monterroso-Rivas. 2019. Identifying cloud forest conservation areas in Mexico from the potential distribution of 19 representative species. Heliyon 5:e01423.

Mandujano, S. 2004. Análisis bibliográfico de los estudios de venados en México. Acta Zoológica Mexicana 20:211-251.

Mandujano, S. 2011. Bibliografía estudios de venados en México. Volumen 2. Instituto Literario de Veracruz S. C. Xalapa, México.

Muñoz, B., ANd S. Gallina. 2014. Evaluación del impacto de la fragmentación del hábitat y la cacería sobre la abundancia de venado temazate (Mazama temama) en una región de la zona Otomí-Tepehua, Hidalgo, México. COMFAUNA, Memorias del $X$ Congreso Internacional de Fauna Silvestre en América Latina. Salta, Argentina.

Muñoz-Vazquez, B., And S. Gallina-Tessaro. 2016. Influencia de la fragmentación del hábitat en la abundancia de Mazama temama a diferentes escalas en un bosque mesófilo de montaña. Therya 7:77-87.

Ortíz-García, A. I., M. I. Ramos-Robles, L. A. Pérez-Solano, and S. Mandujano. 2012. Distribución potencial de los ungulados silvestres en la Reserva de Biosfera de Tehuacán-Cuicatlán, México. Therya 3:333-348.

Pérez-Irineo, G., And A. Santos-Moreno. 2016. Abundance, herd size, activity pattern and occupancy of ungulates in Southeastern Mexico. Animal Biology 66:97-109.

Pérez-Solano, L. A., And S. Mandujano. 2013. Distribution and loss of potential habitat of the Central American red brocket deer (Mazama temama) in the Sierra Madre Oriental, Mexico. Deer Specialist Group 25:1-17.

Pérez-Solano, L. A., S. Mandujano, F. Contreras-Moreno, and J. M. Salazar-Torres. 2012. Primeros registros del temazate rojo Mazama temama en áreas aledañas a la Reserva de la Biosfera de Tehuacán-Cuicatlán, México. Revista Mexicana de Biodiversidad 83:875-878.

Pérez-Solano, L. A., M. G. Hidalgo-Mihart, and S. Mandujano. 2016. Preliminary study of habitat preferences of red brocket deer (Mazama temama) in a mountainous region of central Mexico. Therya 7:197-203.

Ponce-Reyes, R., V-H. Reynoso-Rosales, J. E. M. Watson, J. VanDerWal, R. A. Fuller, R. L. Pressey, and H. P. Possingham. 2012. Vulnerability of cloud forest reserves in Mexico to climate change. Nature Climate Change 2:448-452.

Ramírez-Bravo, O. E., and L. Hernández-Santín. 2012. Nuevos registros del temazate rojo (Mammalia: Artiodactyla: Cervidae: Mazama temama) en el estado de Puebla, México. Acta Zoológica Mexicana 28:487-490.

Reid, F. A. 1997. A field guide to the mammals of Central America and Southeast Mexico. Oxford University Press. New York, U.S.A.

Reyna-Hurtado, R., And G. W. Tanner. 2005. Habitat preferences of ungulates in hunted and nonhunted areas in the Calakmul forest, Campeche, Mexico. Biotropica 37:676-685.

Reyna-Hurtado, R., And G. W. Tanner. 2007. Ungulate relative abundance in hunted and non- hunted sites in Calakmul Forest Southern Mexico. Biodiversity and Conservation 163:743-756.

Secretaría de Medio Ambiente y Recursos Naturales (SEMARNAT). 2010. Norma Oficial Mexicana NOM-059-SEMARNAT-2010, Protección Ambiental-especies nativas de México de flora y fauna silvestres-categorías de riesgo y especificaciones para su inclusión, exclusión o cambio-lista de especies en riesgo. Diario Oficial de la Federación 2454:1-77.

Secretaría de Medio Ambiente y Recursos Naturales (SEMARNAT). 2014. Acuerdo por el que se da a conocer la lista de especies y poblaciones prioritarias para la conservación. Diario Oficial de la Federación (5 de marzo de 2014). México City, México.

Servicios Forestales de Hidalgo (SERFORH). 2011. Estudio Regional Forestal de la Unidad de Manejo Forestal 1302 "Zacualtipán-Molango". Asociación de Productores Forestales de la Región Zacualtipán-Molango A. C. Hidalgo, México.

Servicios Forestales de Hidalgo (SERFORH). 2017. Inventario de la mastofauna terrestre de la cuenca de abasto No. 10 Zacualtipán-Huayacocotla. Silvicultores de la Región Zacualtipán-Molango A. C., CONAFOR. Hidalgo, México.

Unión Internacional para la Conservación de la Naturaleza (UICN). 2016. Mazama temama. Lista Roja de Especies Amenazadas de la UICN. Version 2016-2. https://www.iucnredlist.org. Downloaded on 9 September 2019.

Weber, M. 2008. Un especialista, un generalista y un oportunista: uso de tipos de vegetación por tres especies de venados en Calakmul, Campeche. Pp. 483-496 in Avances en el Estudio de los Mamíferos de México Vol. 2. (Lorenzo, C., E. Espinoza, and J. Ortega, eds.). Asociación Mexicana de Mastozoología, A.C. México City, México.

Weber, M., And S. González. 2003. Latin American deer diversity and conservation: A review of status and distribution. Ecoscience 10:443-454. 
Associated editor: Cristian Kraker-Castañeda

Submitted: February 29, 2020; Reviewed: May 29, 2020.

Accepted: June 1, 2020; Published on line: June 17, 2020. 